\title{
Influence of digoxin-like immunoreactive factor on late complications in patients with diabetes mellitus
}

\author{
R. H. STRAUB,${ }^{*}$ R. ELBRACHT $\dagger$ B. K. KRÄMER ${ }^{\ddagger}$ M. ROTH. ${ }^{*}$ K.-D. PALITZSCH* \& \\ J. SCHÖLMERICH* ${ }^{*}$ Department of Internal Medicine I, $\dagger$ Department of Laboratory Medicine and \\ $\ddagger$ Department of Internal Medicine II, University Hospital, Regensburg, Germany
}

Received 2 September 1993 and in revised form 11 January 1994: accepted 19 January 1994

\begin{abstract}
The aim of this study was to compare the intensity of typical late complications in diabetic patients ( $n=65,28$ type I, 37 type II) who were not on glycoside drugs with low vs. high serum levels of digoxin-like immunoreactive factor (DLIF: group I, $n=42$, DLIF $\leqslant$ the detection limit of $0.2 \mathrm{ng} \mathrm{ml}^{-1}$; and group II, $n=23$, mean \pm SEM: $1 \cdot 17 \pm 0 \cdot 31$ [0.25-4.96] $\mathrm{ng} \mathrm{ml}^{-1}$ ). For detection of nephropathy, urinary albumin excretion $(24 \mathrm{~h})$ and creatinine clearance tests were used. For coronary heart disease a questionnaire and standard ECG; for peripheral occlusive vascular disease a questionnaire; for eye disease a fundoscopy; for neuropathy a neurological score system: and for autonomic neuropathy a standardized test battery was employed. Patients with high DLIF levels showed better test results in vibratory perception $(95.7 \pm 1.5$ vs. $82.8 \pm 3.8 \%$, normal finding $=100 \%$, $2 p=0.016)$, had better percentile localizations concerning maximal pupillary area in darkness $(28 \cdot 4 \pm 6 \cdot 6 \mathrm{vs}$. $8 \cdot 1 \pm 1 \cdot 8 \%, 2 \mathrm{p}=0.0004)$, contraction velocity at $1 \mathrm{~s}$ $(21 \cdot 5 \pm 5.8$ vs. $8 \cdot 0 \pm 2 \cdot 2 \%, 2 \mathrm{p}=0.012)$, and dilation velocity at $6 s(23.0 \pm 6.8$ vs. $10 \cdot 5 \pm 2.5 \%, 2 p=0.041)$, had less retinopathy (with retinopathy: $26 \cdot 1 \%$ vs. $64.3 \%, 2 p=0.0028$ ), and better percentile localizations in the respiratory sinus arrhythmia test $(68 \cdot 4 \pm 7 \cdot 3$ vs. $44 \cdot 1 \pm 4 \cdot 9 \%, 2 p=0 \cdot 0064)$. There was no difference concerning nephropathy, blood pressure, coronary heart disease and peripheral vascular disease. Separate analysis according to the type of diabetes confirmed the results in each group. This would indicate that DLIF is a possible protective endogenous substance for eye disease, and peripheral (large sensory fibres) and autonomic neuropathy in diabetic subjects independent of the type of diabetes.
\end{abstract}

Keywords. Diabetic cardiovascular disease, diabetic nephropathy, diabetic neuropathy, diabetic retinopathy, digoxin-like immunoreactive factor.

This study was orally presented at EASD. European Association for the Study of Diabetes. Istanbul, Turkey, $6 \ldots 9$ September. 1993.

Correspondence: Dr Rainer H. Straub, Department of Internal Medicine I, University Hospital Regensburg. D-93042 Regensburg. Germany.

\section{Introduction}

The sodium-potassium pump is responsible for the gradient of monovalent ions between intracellular and extracellular fluids. Three sodium ions are translocated outwards against two potassium ions inwards per one ATP molecule hydrolysed [1]. This ubiquitous transport system plays a major role in regulating body water content and several cell functions including control of cell volume, excitability and nutrition. Dysfunctions of the pump stem either from intrinsic membrane alterations, action of humoral factors, or both dysfunctions. Endogenous pump inhibitors, the so-called digoxin-like immunoreactive factors (DLIF), have been described in several tissues, such as brain [2-4], kidney [5], adrenal gland [6], and in biological fluids [7-9]. Furthermore, DLIF was found in several physiological and pathophysiological conditions including newborn infants [10], pregnant women [11], hypertensive pregnant women [12], renal failure [13,14], liver disease [15-17], essential hypertension [18-23], diabetes [24-26], obstructive sleep apnoea [27], acromegaly [28] and aneurysmal subarachnoid haemorrhage [29].

With the exception of a recently found endogenous ouabain-like compound [30], the chemical nature of digoxin-like immunoreactive factors is not yet known. Therefore, it is not possible to perform specific RIA assays for DLIF by use of antisera against DLIF, with DLIF as standard. However, it was found that there exists a good correlation between endogenous digoxin-like immunoreactivity measured by digoxin RIA and ${ }^{3} \mathrm{H}$-ouabain displacement on erythrocyte membranes in humans [31]. In accordance with Clerico et al. [32], it is thought that digoxin RIA methods can be useful for DLIF determination because they are generally more sensitive, precise and simple than other techniques used to detect endogenous digitalislike factors. However, immunological methods should be used only as preliminary tests to detect the possible presence of DLIF in human biological fluids.

In this respect it was the aim of the study to compare the intensity of typical late complications in diabetic patients, with and without measurable 
serum digoxin, using a standard immunological method. Known interference from drugs or severe disease states have been widely ruled out.

\section{Patients and methods}

\section{Patients}

Sixty-five diabetic outpatients (28 type I, 37 type II) with a mean age of $47 \cdot 1 \pm 2 \cdot 2$ years $(14-76 \mathrm{y})$ were studied after they had given informed consent. The clinical parameters of patients under study are shown in Table 1. None of these 65 patients received cardiac glycosides, spironolactone, prednisone or cortisone which is known to interfere with detection of digoxin immunoreactivity. Because of possible false positive measurements, all the patients were ensured to have near normal levels of serum triglycerides, serum cholesterol, haemoglobin Alc, serum sodium, serum potassium, serum bilirubin, serum protein, serum albumin, haemoglobin, leucocytes, platelets and haematocrit. The groups did not differ statistically significantly in the above-mentioned laboratory parameters. High sodium intake is known to increase the plasma concentration of $\mathrm{Na} / \mathrm{K}$-ATPase inhibitor [21]. Therefore, sodium diet might influence the results. Hence, $24 \mathrm{~h}$ urinary sodium and potassium excretion have to be similiar in the two study groups (Na: group I vs. group II: $137 \cdot 4 \pm 11 \cdot 8$ vs. $140 \cdot 7 \pm 14 \cdot 0$ $\mathrm{mmold}^{-1} ; \mathrm{K}: 53.7 \pm 5.9$ vs. $\left.61.9 \pm 5.4 \mathrm{mmol} \mathrm{d}^{-1}\right)$. None of the patients had severe pre-terminal renal failure (exclusion of patients with serum creatinine greater than $3.0 \mathrm{mg} \mathrm{dl}^{-1}$, serum urea greater than $100 \mathrm{mg} \mathrm{dl}^{-1}$ and/or nephrotic proteinuria) or hepatic disease or pregnancy, and all had normal serum electrolyte levels. Furthermore, the presence of ventricular dysfunction was widely ruled out and from clinical aspects the patients had mild to moderate congestive heart failure distributed equally in both groups (exclusion of patients with heart failure of more than NYHA functional class II). The patients were then divided into two groups according to their level of digoxin immunoreactivity. The first group consisted of patients with a DLIF level $\leqslant$ the detection limit of $0.2 \mathrm{ng} \mathrm{ml}^{-1}(n=42)$ and the second group of patients with DLIF above $0.2 \mathrm{ng} \mathrm{ml}^{-1}(n=23)$. They were not different in clinical parameters (Table 1).

\section{Patients' specimens}

On the day the patients returned their $24 \mathrm{~h}$ urine collection ( 08.00 hours), which they undertook a day before, a urine specimen was taken for the determination of urine creatinine, urine albumin, urine sodium and urine potassium. Furthermore, blood was drawn at the same time for the determination of serum cholesterol, serum triglycerides, haemoglobin Alc, serum creatinine for endogenous creatinine clearance, serum sodium, serum potassium, serum bilirubin, total serum protein, serum albumin, haemoglobin, leucocytes, platelets and haematocrit using standard techniques.

\section{Measurement of digoxin-like immunoreactive factor}

Several studies showed that the TDX system (Abbott GmbH Diagnostika, Wiesbaden, Germany) can measure DLIF, but compared to other immunological techniques the interference was generally less than that seen in commonly used RIAs for digoxin [33, 34]. This may be due to the recommended removal of serum proteins for the use of this technique [35]. The cross-reactivity of the TDX system for cholesterol, cortisol, dehydroepiandrosterone sulfate, estriol, prednisolone, progesterone, 11- $\alpha$-hydroxyprogesterone, 17- $\alpha$-hydroxyprogesterone and testosterone was below $1 \%$. The coefficient of variation for this kit was clearly below $8 \%$ and the average analytical recovery of digoxin was about $100 \%$. Hence, in order to minimize interferences the TDX system was used in this study.

Before digoxin immunoreactivity measurement by

Table 1. Clinical parameters (mean \pm SEM) of patients under study. Percentages are given in parentheses and ranges in brackets. DLIF, digoxin-like immunoreactive factor

\begin{tabular}{|c|c|c|}
\hline & $\begin{array}{l}\text { DLIF } \leqslant \text { the detection } \\
\text { limit of } 0 \cdot 20 \mathrm{ng} \mathrm{ml}^{-1}\end{array}$ & $\begin{array}{l}\text { DLIF above detection } \\
\text { limit of } 0.20 \mathrm{ng} \mathrm{ml}^{-1}\end{array}$ \\
\hline DLIF [ng ml $\left.{ }^{-1}\right]$ & $\leqslant 0 \cdot 20 \mathrm{ng} \mathrm{ml}^{-1}$ & $1 \cdot 17 \pm 0 \cdot 31[0 \cdot 25-4 \cdot 9]$ \\
\hline$n$ & $42(64 \cdot 6 \%)$ & $23(35.4 \%)$ \\
\hline Age $[y]$ & $48 \cdot 8 \pm 2 \cdot 6$ & $43 \cdot 9 \pm 4 \cdot 1$ \\
\hline Female & $30(71 \cdot 4 \%)$ & $14(60 \cdot 9 \%)$ \\
\hline Male & $12(28 \cdot 6 \%)$ & $9(39 \cdot 1 \%)$ \\
\hline Body mass index $\left[\mathrm{kg} \mathrm{m}^{-2}\right]$ & $25 \cdot 6 \pm 0 \cdot 8$ & $24 \cdot 4 \pm 1 \cdot 1$ \\
\hline Duration [y] & $14 \cdot 4 \pm 1 \cdot 5$ & $15 \cdot 8 \pm 2 \cdot 6$ \\
\hline Type [I/II] & $18 / 24(42.9 \% / 57 \cdot 1 \%)$ & $10 / 13(43 \cdot 5 \% / 56 \cdot 5 \%)$ \\
\hline Smoker & $9(21 \cdot 4 \%)$ & $7(30 \cdot 4 \%)$ \\
\hline Daily insulin need [IU] (all types of diabetes) & $28 \cdot 7 \pm 3 \cdot 6$ & $25 \cdot 5 \pm 3 \cdot 9$ \\
\hline Patients under sulphonylureas & $11(26 \cdot 2 \%)$ & $6(26 \cdot 1 \%)$ \\
\hline Patients under metformin & $2(4 \cdot 8 \%)$ & $1(4 \cdot 3 \%)$ \\
\hline
\end{tabular}


fluorescence polarization immunoassay (FPIA), serum protein was precipitated using 5-sulfosalicylic acid in equivolume methanol/water in accordance with the manufacturer's recommendations. This mixture was centrifugated at $9500 \times g$ at $20^{\circ} \mathrm{C}$ and digoxin was measured in the resulting supernate. All the digoxin determinations were carried out with the Abbott TDX analyser with original Abbott FPIA reagents. FPIA digoxin immunoreactivity in patients' samples was extrapolated from fluorescence polarization data stored in the TDX, consisting of analytical standards from Abbott: $0 \cdot 0,0 \cdot 5,1 \cdot 0,2 \cdot 0$, 3.0 and $5.0 \mathrm{ng} \mathrm{ml}^{-1}$. Standard TDX software compensated for twofold dilution of the sample with 5sulfosalicylic acid in reporting digoxin results. The detection limit for digoxin recommended by the manufacturer for 5-sulfosalicylic acid precipitation and FPIA method was $0.2 \mathrm{ng} \mathrm{ml} \mathbf{m}^{-1}$. This detection limit is confirmed by others [36].

\section{Evaluation of diabetic late complications}

For the detection of nephropathy, $24 \mathrm{~h}$ urinary albumin excretion and endogenous creatinine clearance are used; for coronary heart disease a questionnaire and standard 12-lead electrocardiograms at rest; for peripheral occlusive vascular disease a questionnaire; and for eye disease the evaluation of the fundus by an ophthalmologist were used. Autonomic neuropathy was assessed by a battery of tests including standardized cardiovascular (variation coefficient of $\mathrm{R}-\mathrm{R}$ intervals, respiratory sinus arrhythmia test = RSA, Valsalva test lying-to-standing test; [37]) and pupillometric investigations (latency time of pupillary light reflex, maximal pupillary area in darkness, contraction velocity at $1 \mathrm{~s}$, dilation velocity at $6 \mathrm{~s}$ [38]). Peripheral neuropathy was assessed by measuring test groups as vibratory perception with a tuning fork (left and right: great toe, medial malleolus, medial epicondyle of the femur), temperature perception by means of a cold $\left(22^{\circ} \mathrm{C}\right)$ and warm $\left(30^{\circ} \mathrm{C}\right)$ metal disc (left and right: back of the foot, tibia, back of the hand, fingers) and reflexes (biceps brachii, triceps brachii, quadriceps femoris, triceps surae). On each of the mentioned three test groups a patient can obtain 100 points which indicates a completely normal function ( $=100 \%$ function). According to an international consensus conference, patients with $24 \mathrm{~h}$ urinary albumin excretion of more than $30 \mathrm{mg}$ $\mathrm{d}^{-1}$ were said to have albuminuria [39].

\section{Statistical analysis}

Multiple group means were compared by ANOVA (SPSS/PC + Advanced Statistics V4.0. SPSS Inc., Chicago, IN, USA). For autonomic function tests, the exact percentile localization derived from data of earlier studies were used $[37,38]$. Values are expressed as mean \pm SEM unless otherwise stated and $2 p=0.05$ is the significant level.

\section{Results}

\section{Frequency and level of measurable DLIF}

From a total of 28 type I diabetic patients $10(35.7 \%)$ and from 37 type II diabetic patients $13(35 \cdot 1 \%)$ had a measurable DLIF level (all patients together: $35 \cdot 4 \%$ ). The average level in the 10 type I diabetic patients was $1 \cdot 1 \pm 0.4 \mathrm{ng} \mathrm{ml}^{-1}(0 \cdot 25-4 \cdot 6)$ and $1 \cdot 2 \pm 0.4 \mathrm{ng} \mathrm{ml}^{-1}$ $(0.25-4.96)$ in the 13 type II diabetic patients, respectively. The average level in all patients with a measurable DLIF was $1 \cdot 2 \pm 0 \cdot 3 \mathrm{ng} \mathrm{ml}^{-1}$.

\section{Diabetic late complications}

Table 2 summarizes the data of patients with an undetectable DLIF level and those with a measurable DLIF level. There was no difference in endogenous creatinine clearance, $24 \mathrm{~h}$ urinary albumin excretion, frequency of peripheral occlusive vascular disease (pOVD) and coronary heart disease (CHD) between the two groups. Furthermore, the two groups were not different in systolic and diastolic blood pressure but a trend towards higher values in the group with low DLIF level seemed to exist. Retinopathy was clearly more frequent in patients with a low DLIF level $(2 p=0.003)$. Beyond that, pupillometric parameters as maximal pupillary area $(2 p=0.0004)$, contraction velocity at $1 \mathrm{~s}(2 \mathrm{p}=0.012)$, dilation velocity at $6 s(2 p=0.041)$ and the result of the cardiorespiratory RSA test $(2 p=0.006)$ were much better in patients with a measurable DLIF than in those with an undetectable level. The clinical neurological tests revealed a better test result in sensory large fibre function (vibration perception) in patients with high DLIF levels $(2 p=0.016)$. In all the neurological tests (autonomic and peripheral) where no significant difference could be found, a trend towards better test results in diabetic patients with a high DLIF level seemed to exist. This is also true for the $24 \mathrm{~h}$ urinary albumin excretion, which differed nearly statistically significantly in type II diabetic patients (patients with a $24 \mathrm{~h}$ urinary albumin excretion of more than $30 \mathrm{mg} \mathrm{d}^{-1}$ : group I vs. II: $73.9 \%$ vs. $41 \cdot 7 \%$, $2 p=0.067$ ).

Figure 1 shows the results of fundoscopy and vibration perception testing of type I and type II diabetic patients with a high and low DLIF level. Type I diabetic patients with high DLIF levels had significantly less retinopathy than patients with low DLIF levels (30.0\% vs. $70.6 \%, 2 p=0.042)$. This could also be confirmed in type II diabetic patients $(23.1 \%$ vs. $62.5 \%, 2 p=0.022$ ). Considering vibratory perception, type II diabetic patients with high DLIF level had better sensory large fibre function than patients with low DLIF $(94.5$ vs. $78.6 \%, 2 p=0.036)$. This was not statistically significant in the smaller group of type I diabetic patients but there was a similar trend.

With regard to autonomic neuropathy, the maximal pupillary area was higher in type I and type II 
Table 2. Parameters (mean \pm SEM) of diabetic late complications of patients under study. Percentages are shown in parentheses. DLIF, digoxinlike immunoreactive factor; pOVD, peripheral occlusive vascular disease; CHD, coronary heart disease; RSA, respiratory sinus arrythmia; Pe, percentile localization in [\%]

\begin{tabular}{|c|c|c|c|}
\hline & $\begin{array}{l}\text { DLIF } \leqslant \text { the detection } \\
\text { limit of } 0 \cdot 20 \mathrm{ng} \mathrm{ml}^{-1}\end{array}$ & $\begin{array}{l}\text { DLIF above detection } \\
\text { limit of } 0 \cdot 20 \mathrm{ng} \mathrm{ml}^{-1}\end{array}$ & $2 \mathrm{P}$ \\
\hline \multicolumn{4}{|l|}{ Kidney disease } \\
\hline Patients with a creatinine clearance of less than $70 \mathrm{ml} \mathrm{min}^{-1}$ & $21.9 \%$ & $13 \cdot 0 \%$ & $0 \cdot 389$ \\
\hline Patients with a $24 \mathrm{~h}$ urinary albumin excretion of more than $30 \mathrm{mg} \mathrm{d}^{-1}$ & $65 \cdot 0 \%$ & $45 \cdot 5 \%$ & $0 \cdot 140$ \\
\hline \multicolumn{4}{|l|}{ Cardiovascular disease } \\
\hline Systolic blood pressure $[\mathrm{mmHg}]$ & $138 \cdot 0 \pm 3 \cdot 5$ & $132 \cdot 6 \pm 4 \cdot 0$ & $0 \cdot 341$ \\
\hline Diastolic blood pressure $[\mathrm{mmHg}]$ & $80 \cdot 3 \pm 1 \cdot 9$ & $77 \cdot 2 \pm 2 \cdot 3$ & $0 \cdot 316$ \\
\hline Patients with a systolic blood pressure of more than $140 \mathrm{mmHg}$ & $38 \cdot 1 \%$ & $30 \cdot 4 \%$ & $0 \cdot 554$ \\
\hline Patients with a diastolic blood pressure of more than $90 \mathrm{mmHg}$ & $11.9 \%$ & $4.4 \%$ & $0 \cdot 322$ \\
\hline With pOVD & $7(16 \cdot 7 \%)$ & $5(21 \cdot 7 \%)$ & $0 \cdot 621$ \\
\hline With CHD & $10(23 \cdot 8 \%)$ & $6(26 \cdot 1 \%)$ & $0 \cdot 842$ \\
\hline \multicolumn{4}{|l|}{ Eye disease } \\
\hline With retinopathy (all stages) & $27(64 \cdot 3 \%)$ & $6(26 \cdot 1 \%)$ & $0 \cdot 003$ \\
\hline \multicolumn{4}{|l|}{$\begin{array}{l}\text { Autonomic neuropathy } \\
\text { Pupillary }\end{array}$} \\
\hline Pe. in latency time & $24 \cdot 0 \pm 4 \cdot 3$ & $21 \cdot 1 \pm 4 \cdot 3$ & $0 \cdot 665$ \\
\hline $\mathrm{Pe}$. in maximal pupillary area & $8 \cdot 1 \pm 1 \cdot 8$ & $28 \cdot 4 \pm 6 \cdot 6$ & 0.0004 \\
\hline $\mathrm{Pe}$. in contraction velocity at $1 \mathrm{~s}$ & $8 \cdot 0 \pm 2 \cdot 2$ & $21 \cdot 5 \pm 5 \cdot 8$ & 0.012 \\
\hline $\mathrm{Pe}$. in dilation velocity at $6 \mathrm{~s}$ & $10 \cdot 5 \pm 2 \cdot 5$ & $23 \cdot 0 \pm 6 \cdot 8$ & $0 \cdot 041$ \\
\hline \multicolumn{4}{|l|}{ Cardiorespiratory } \\
\hline Pe. in RSA test & $44 \cdot 1 \pm 4 \cdot 9$ & $68 \cdot 4 \pm 7 \cdot 3$ & $0 \cdot 006$ \\
\hline$P e$. in var. coeff. of $R-R$ intervals & $33 \cdot 8 \pm 5 \cdot 1$ & $44 \cdot 8 \pm 6 \cdot 5$ & $0 \cdot 196$ \\
\hline Pe. in Valsalva test & $27 \cdot 6 \pm 4 \cdot 1$ & $30 \cdot 5 \pm 5 \cdot 9$ & 0.676 \\
\hline Pe. in Ewing test & $20 \cdot 9 \pm 4 \cdot 4$ & $28 \cdot 4 \pm 6 \cdot 2$ & $0 \cdot 324$ \\
\hline \multicolumn{4}{|l|}{ Neuropathy } \\
\hline Vibratory perception [\%] & $82.8 \pm 3.8$ & $95 \cdot 7 \pm 1 \cdot 5$ & 0.016 \\
\hline Reflex status [\%] & $78 \cdot 3 \pm 3 \cdot 2$ & $80 \cdot 4 \pm 5 \cdot 1$ & $0 \cdot 713$ \\
\hline Temperature perception [\%] & $83 \cdot 8 \pm 2 \cdot 7$ & $89 \cdot 4 \pm 4 \cdot 1$ & $0 \cdot 240$ \\
\hline
\end{tabular}

diabetic patients with high compared to low DLIF levels (type I: $30 \cdot 1$ vs. $7 \cdot 8 \%$ percentile, $2 p=0.031$ and type II: $27 \cdot 0$ vs. $8 \cdot 5 \%$ percentile, $2 p=0 \cdot 007$, Fig. 2 ). This could be confirmed in type II diabetic patients considering the test results in RSA test (high DLIF: $68 \cdot 1$ vs. low DLIF: $35 \cdot 7 \%$ percentile, $2 p=0.007$ ).

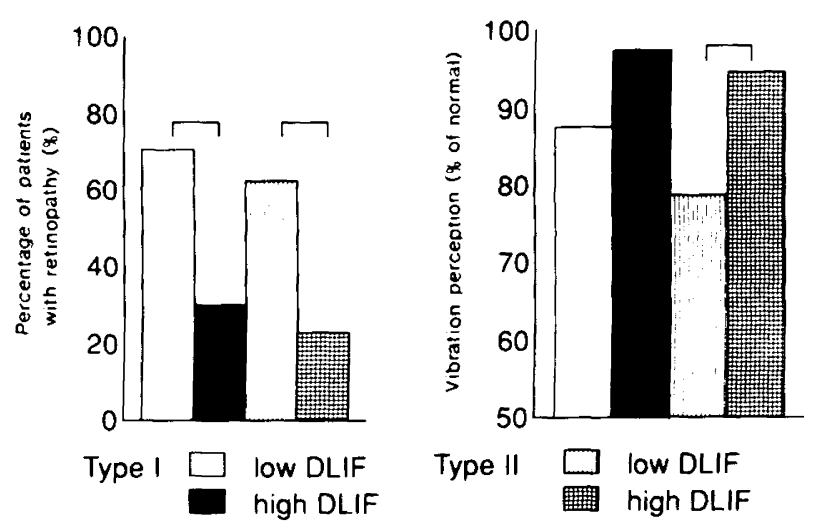

Figure 1. Results in patients with high and low levels of digoxin-like immunoreactive factor (DLIF) in type I and type II diabetic patients. (Left) Percentage of type I and type II diabetic patients with retinopathy. (Right) Result in the vibratory perception test in type I and type II diabetic patients. According to the definition, a finding of $100 \%$ is normal and a finding below $80 \%$ is neuropathic.

\section{Discussion}

65 type I and type II diabetic patients were screened for digoxin-like immunoreactive factor. About $35 \%$ of all patients showed a measurable DLIF level with an average of $1.2 \mathrm{ng} \mathrm{ml}^{-1}$. It was shown that patients with high DLIF levels in serum had less severe late complications compared to those with a low DLIF

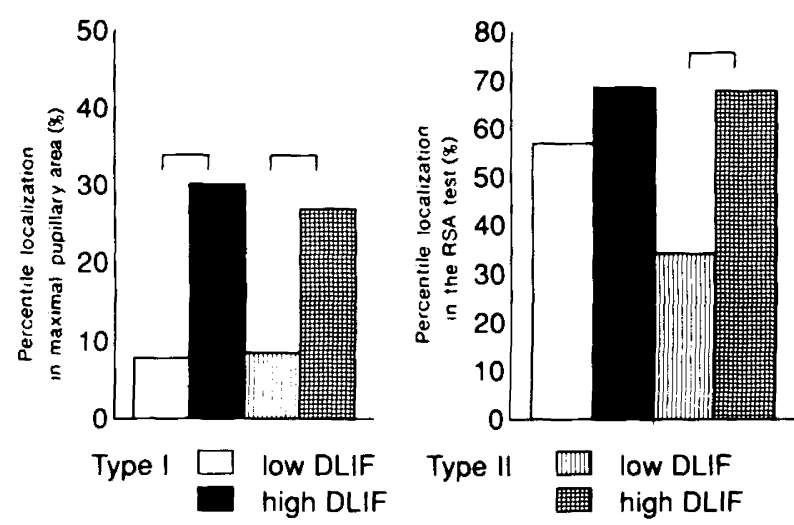

Figure 2. Results in patients with high and low levels of digoxin-like immunoreactive factor (DLIF) in type I and type II diabetic patients. (Left) Average percentile localization of maximal pupillary area in darkness. (Right) Average percentile localization in the autonomic function test of respiratory sinus arrhythmia. 
serum level, especially regarding retinopathy and autonomic and peripheral neuropathy. This could also be confirmed when dividing the total group in type I and type II diabetic subgroups. Retinopathy, peripheral and autonomic neuropathy seem to be the only complications linked with the DLIF levels. However, the correlation between nephropathy and DLIF seems to exist at least in form of a trend. Moreover, if coronary heart disease and peripheral occlusive vascular disease were assessed with the same accurate techniques, which were not available, compared to the assessment of neuropathy, retinopathy and nephropathy a difference between the two groups might be demonstrable concerning the two late complications. To our knowledge, this is the first study that compares late complication in diabetic patients with respect to different DLIF serum levels. There have been several reports showing that DLIF was high in patients with essential hypertension [18-23] and one group had shown that type II diabetic patients with a family history of hypertension had higher DLIF levels [25]. It has been shown that patients with acromegaly and chronic volume expansion have decreased levels of DLIF and plasma volume after pituitary adenomectomy [28]. Furthermore, pregnant women and their newborn infants have high DLIF levels which decrease rapidly after birth $[10,11]$. This may be also due to volume expansion in the perinatal period. From animal experiments it is known that volume expansion and salt-loading increases DLIF levels [4,7,8]. This could also be confirmed in humans [40]. From this point of view, DLIF levels seem to be increased secondarily in saltloaded and volume-expanded subjects and probably not vice versa. Nevertheless, it should be mentioned that there are some studies which argue against the volume expansion hypothesis. It is said that DLIF lead to exaggerated vascular smooth muscle contraction and to an elevation of peripheral vascular resistance due to an increase in cytosolic free calcium concentration [41]. Furthermore, reducing the sodium pump activity may exaggerate neural stimulation and norepinephrine overflow [42] which, together with increased vascular resistance, might explain, at least in part, hypertension. But it is still a matter of debate whether DLIF is primarily high in some subjects then perhaps leading to hypertension, or secondarily as a consequence of volume expansion to counteract hypertension.

In diabetes mellitus there are some important factors for volume expansion which are increased insulin level, increased growth hormone level, increased sympathetic activity and high water intake because of high blood glucose levels [2,8,20,30,43-52]. Moreover, it is possible that inadequately high cortisol production rates as found in obese subjects [53] may contribute to volume expansion in type II diabetic patients, too. In later disease states, severe diabetic nephropathy also leads to volume expansion. but this appeared to be of no importance in this study.
These mechanisms have to be counteracted by a feedback control system that protects the subject from hypertension. The antagonistic factors leading to volume contraction are inhibition of the secretion of vasopressin, renin and aldosterone, stimulation of the secretion of atrial natriuretic peptide and digoxinlike immunoreactive factor(s), and local renal prostaglandin (E1, E2, 12) mechanisms [2,20,30,44,52].

In conclusion, and under consideration of the recent report showing that DLIF may be in part endogenous ouabain [30], lack of DLIF secretion in diabetic patients may be a factor leading to alterations in regulation of body water content and several cell functions including control of cell volume, excitability and nutrition due to intracellular and extracellular volume expansion. This in fact may lead to a diffusion barrier for vital nutrients in susceptible bradytrophic tissues such as retina and nerve. Hence, diabetic patients with low DLIF of unknown origin may be more susceptible for late complications due to volume expansion and lowered tissue perfusion. The somewhat speculative question arises as to whether administration of low doses of digoxin or ouabain may be protective in diabetic patients. Before administration of such drugs in a controlled prospective study, a larger cross-sectional survey would have to confirm our findings.

\section{References}

1 Garrahan PJ. Glynn IM. The stoichiometry of the sodium pump. J Physiol 1967:192:217-35.

2 Haupert GT, Sancho JM. Sodium transport inhibitor from bovine hypothalamus. Proc Natl Acad Sci USA 1979:76:465860.

3 Fishman $M$. Endogenous digitalis-like activity in mammalian brain. Proc Natl Acad Sci USA 1979:76:4661-3.

4 Takahashi H. Matsusawa M. Suga K et al. Hypothalamic digitalis-like substance is released with sodium-loading in rats. Am J Hypertens 1988;1:146-51.

5 Raghavan SR. Gonick HC. Partial purification and characterization of natriuretic factor from rat kidney. Proc Soc Exp Biol Med 1980:164:101-4.

6 Tamura M, Lam T-T. Inagami T. Isolation and characterization of a specific endogenous Na.K-ATPase inhibitor from bovine adrenal. Biochemistry 1988:27:4244-53.

7 Clarkson EM. Raw SM. De Wardener HE. Two natriuretic substances in extracts of urine from normal man when saltdepleted and salt-loaded. Kidney Int 1979:16:710-21.

8 Gruber KA. Whitaker JM. Buckalew VM Jr. Endogenous digitalis-like substance in plasma of volume-expanded dogs. Nature 1980:287:743-5.

9 Licht A. Stein S. McGregor CW. Bourgoignie JJ. Bricker NS. Progress in isolation and purification of an inhibitor of sodium transport obtained from dog urine. Kidney Int 1982:21:339-44.

10 Valdes R Jr. Graves SW. Brown BA. Landt M. Endogenous substance in newborn infants causing false positive digoxin measurements. J Pediatr 1983:102:947-50.

11 Graves SW. Valdes R Jr. Brown BA. Knight AB. Craig HR. Endogenous digoxin-immunoreactive substance in human pregnancies. J Clin Endocrinol Metab 1984:58:748-51.

12 Valdes R Jr. Graves SW. Knight AB. Craig HR. Endogenous digoxin-immunoactivity is elevated in hypertensive pregnancy. In: Lal H. LaBella F. Lane J, eds. Endocoids. New York: Liss. 1985:229- 32

13 Graves SW. Brown BA. Valdes R Jr. Digoxin-like substance in patients with renal impairment. Ann Intern Med 1983:99:604-8. 
14 Gault MH, Vasdev SC, Longerich LL. Endogenous digoxin-like substance(s) and combined hepatic and renal failure. Ann Intern Med 1984;101:567-8

15 Nanjii AA, Greenway RC. Falsely raised plasma digoxin concentration in liver disease. Br Med J 1985;290:432-3.

16 Shilo L, Shapiro MS. Dolev S, Shenkman L. Endogenous digoxin-like material in patients with liver disease (Letter). Ann Intern Med 1985;103:643.

17 Rosenkranz B. Frölich JC. Falsely elevated digoxin concentrations in patients with liver disease. Ther Drug Monitor 1985:7:205-6.

18 Hamlyn JM. Ringel R. Schaeffer $J$ et al. A circulating inhibitor of Na K-ATPase associated with essential hypertension. Nature 1982:300:650-2.

19 Devynck M-A. Pernollet M-G, Rosenfeld JB, Meyer P. Measurement of digitalis-like compound in plasma: application in studies of essential hypertension. Br Med J 1983:287:631-4.

20 Haddy FJ, Pamnani MB. Evidence for a circulating endogenous $\mathrm{Na}-\mathrm{K}$ pump inhibitor in low-renin hypertension. Fed Proc 1985;44:2789-94.

21 Hasegawa T, Masugi F, Ogihara T, Kumahara Y. Increase in plasma ouabainlike inhibitor of $\mathrm{Na}$. K-ATPase with high sodium intake in patients with essential hypertension. J Clin Hypertens 1987;3:419-29.

22 Saitoh S, Shimamoto K. Nakagawa M et al. The pathophysiological role of digitalis-like substance in essential hypertension. $\mathbf{J}$ Hypertension 1988:6(Suppl 4):S360-2.

23 Cloix J-F, Crabos M, Grichois M-L, Guicheney P. Meyer P. Endogenous $\mathrm{Na}$ transport inhibitor in human hypertension: further biochemical and chemical studies. Klin Wochenschr 1987;65(Suppl VIII): 146-53.

24 Giampietro O, Clerico A, Gregori G et al. Increased urinary excretion of digoxin-like immunoreactive substance by insulindependent diabetic patients: a linkage with hypertension? Clin Chem 1988; 34:2418-22.

25 Okamoto S, Ikeda M, Morise T, Miyamori I, Takeda R. Elevated endogenous Na-K-ATPase inhibitor activity in hypertensive diabetic patients with a family history of hypertension. $J$ Diab Complications 1991;5:146-7.

26 Andronico G. Mulé G, Mangano MT et al. Insulin resistance and endogenous digoxin-like factor in obese hypertensive patients with glucose intolerance. Acta Diabetol 1992;28:203-5.

27 Ehlenz K. Peter JH. Kaffarnik H, von Wichert P. Disturbances in volume regulating hormone system-a key to the pathogenesis of hypertension in obstructive sleep apnea syndrome? Pneumologie 1991:45:239-45.

28 Deray G. Rieu M. Devynck MA et al. Evidence of an endogenous digitalis-like factor in the plasma of patients with acromegaly. N Engl J Med 1987:316:575-80.

29 Wijdicks EFM, Vermeulen M, van Brummelen P, den Boer NC, van Gijn J. Digoxin-like immunoreactive substance in patients with aneurysmal subarachnoid haemorrhage. Br Med J 1987: 294:729-32.

30 Hamlyn JM, Blaustein MP, Bova S $e t$ al. Identification and characterization of an ouabain-like compound from human plasma. Proc Natl Acad Sci USA 1991:88:6259-63.

31 Balzan S. Ghione S. Clerico A, Montali U. Correlation between endogenous digoxin-like immunoreactivity and ${ }^{3} \mathrm{H}$-ouabain displacement on erythrocyte membranes in extracts of human plasma. Clin Biochem 1986;19:311-4

32 Clerico A. Ghione S. Del Chicca MG. Balzan S. Problems in standardization of digitalis-like substance assay by means of competitive immunological methods. Clin Chem 1987:33:3401.

33 Yatscoff RW, Desjardins PRE, Dalton JG. Digoxin-like immunoreactivity in the serum of neonates and uremic patients, as measured in the Abbott TDx (Letter). Clin Chem 1984;30:588.
34 Greenway DC, Nanji AA. Falsely increased results for digoxin in sera from patients with liver disease: ten immunoassay kits compared. Clin Chem 1985:31:1078-9.

35 Valdes R Jr, Graves SW. Protein binding of endogenous digoxin-immunoactive factors in human serum and its variation with clinical condition. J Clin Endocrinol Metab 1985;60:1135-43.

36 Christenson RH, Studenberg SD, Beck-Davis S, Sedor FA. Digoxin-like immunoreactivity eliminated from serum by centrifugal ultrafiltration before fluorescence polarization immunoassay of digoxin. Clin Chem 1987;33:606-8.

37 Ziegler D, Laux G, Dannehl K et al. Assessment of cardiovascular autonomic function: age-related normal ranges and reproducibility of spectral analysis, vector analysis and standard tests of heart rate variation and blood pressure responses. Diabetic Medicine 1991:9:166-75.

38 Straub RH, Thies U, Kerp L. The pupillary light reflex. 1. Agedependent and age-independent parameters in normal subjects. Ophthalmologica 1992;204:134-42.

39 Mogensen CE, Chacati A, Christensen CK et al. Microalbuminuria: an early marker of renal involvement in diabetes. Uremia Invest 1986;9:85-95

40 Gault MH, Vasdev SC, Longerich LL et al. Plasma digitalis-like factor(s) increase with salt loading (Letter). New Engl J Med 1984:309:1459.

41 Goto A, Yamada K. Ishii $M$ et al. Urinary sodium pump inhibitor raises cytosolic free calcium concentration in rat aorta. Hypertension 1989;13:916-21.

42 Tsuda K. Tsuda S. Shima H, Masuyama Y. Facilitatory effects of ouabain and digitalis-like substance on adrenergic transmission in hypertension. Am J Hypertens 1989:2:465-7.

43 De Wardener HE, Clarkson EM. Natriuretic hormone. In: Seldin DW, Giebisch G, eds. The Kidney: Physiology and Pathophysiology. New York: Raven Press, 1985:1013-31.

44 Shilo L, Pomeranz A, Rathaus M, Weiss E, Bernheim J, Shenkman L. Atrial natriuretic peptide administration to normal and salt depleted rats - effects on digoxin-like immunoreactive factor, aldosterone, ACTH and adrenal function. Life Sci 1988;42:1855-9.

45 Landsberg L, Krieger DR. Obesity, metabolism and the sympathetic nervous system. Am J Hypertens 1989;2(Suppl):125-32.

46 DiBona GF, Sawin LL. Renal nerve activity in saline volume expansion: studies in conscious rats on varying sodium diet. Kidney Int 1983;23:253.

47 Dustan HP. Obesity and hypertension. Diabetes Care 1991:14:488-504.

48 Wiesmann WP. Sinha S, Klahr S. Insulin stimulates active sodium transport in toad bladder by two mechanisms. Nature 1976:260:546-7.

49 Rostand SG, Watkins JB, Clements RS Jr. The effect of insulin and anti-insulin serum on handling of sodium by the isolated, perfused kidney of the streptozotocin-diabetic rat. Diabetes 1980:29:679-85.

50 Barlet-Bas C, Doucet A. Triiodothyronine enhances renal response to aldosterone in the rabbit collecting tubule. $\mathrm{J}$ Clin Invest 1987;79:629-31.

51 Beck-Nielsen $H$. Clinical disorders of insulin resistance. In: Alberti KGMM, DeFronzo RA, Keen $H$, Zimmet $P$, eds. International Textbook of Diabetes Mellitus. Chichester: John Wiley \& Sons, 1992:531-50.

52 Foegh ML. Hecker M, Ramwell PW. The eicosanoids: prostanglandins. thromboxanes, leukotrienes, and related compounds. In: Greenspan FS. ed. Basic and Clinical Endocrinology. East Norwalk: Appleton \& Lange, 1991:53-65.

53 O'Connell M, Danforth E Jr, Horton ES, Salans L, Sims EAH. Experimental obesity in man. III. Adrenocortical function. J Clin Endocrinol Metab 1973:36:323-9. 